\title{
Distribution of Selected Toxic Elements in Water Phases of River Ogbere, Ibadan, Nigeria
}

\author{
Chibueze Godwin Achi* ${ }^{\circledR}$, Ayodetimi Moyin Omoniyi ${ }^{\circledR}$, Akinwale Oladotun Coker ${ }^{\circledR}$ \\ Department of Civil Engineering, Faculty of Technology, University of Ibadan, Ibadan, Nigeria \\ Email: *achicgjr@gmail.com
}

How to cite this paper: Achi, C.G., Omoniyi, A.M. and Coker, A.O. (2021) Distribution of Selected Toxic Elements in Water Phases of River Ogbere, Ibadan, Nigeria. Journal of Environmental Protection, 12, 429-437.

https://doi.org/10.4236/jep.2021.127026

Received: June 1, 2021

Accepted: July 3, 2021

Published: July 6, 2021

Copyright $\odot 2021$ by author(s) and Scientific Research Publishing Inc. This work is licensed under the Creative Commons Attribution International License (CC BY 4.0).

http://creativecommons.org/licenses/by/4.0/

\begin{abstract}
Rivers in Nigeria are faced with increasing contamination of both solid and liquid wastes that enter the surrounding water bodies, and some of these are toxic pollutants that settle onto the riverbed (the ultimate sink of contaminants in the aquatic environment). These toxic pollutants are released into the aquatic environments and inadvertently pose serious public health risks and hazards. This study aims to assess the level of potentially toxic element in River Ogbere water in the city of Ibadan. A total of 12 surface water samples collected from River Ogbere in Ibadan during the dry and wet season of 2019 was analysed for $\mathrm{pH}$, EC, Iron ( $\mathrm{Fe})$, Manganese $(\mathrm{Mn})$, Zinc $(\mathrm{Zn})$, Copper $(\mathrm{Cu})$, Cadmium $(\mathrm{Cd})$, Chromium $(\mathrm{Cr})$, Lead $(\mathrm{Pb})$ and Nickel $(\mathrm{Ni})$. The $\mathrm{pH}$ was found in the alkaline range $(7.40-7.83)$ while the conductance was obtained in the range of $236.67-353.3 \mu \mathrm{s} / \mathrm{cm}$ in both seasons. $\mathrm{Fe}, \mathrm{Mn}, \mathrm{Zn}, \mathrm{Cu}$, $\mathrm{Cr}, \mathrm{Pb}$, and $\mathrm{Ni}$ were detected in all the samples in the range $0.10-5.44 \mathrm{mg} / \mathrm{L}$, $3.20-5.03 \mathrm{mg} / \mathrm{L}, 0.12-1.27 \mathrm{mg} / \mathrm{L}, 0.03-0.51 \mathrm{mg} / \mathrm{L}, 0.03-0.68 \mathrm{mg} / \mathrm{L}, 0.01-$ $0.75 \mathrm{mg} / \mathrm{L}$ and $0.01-0.03 \mathrm{mg} / \mathrm{L}$ in both seasons respectively, whereas $\mathrm{Cd}$ was detected only in $75 \%$ of the samples $(0.00-0.07 \mathrm{mg} / \mathrm{L})$. Overall seasonal variation was significant for $\mathrm{Fe}, \mathrm{Mn}, \mathrm{Pb}, \mathrm{Cd}$, and $\mathrm{Cr}$. The maximum mean concentration of $\mathrm{Fe}(5.44 \mathrm{mg} / \mathrm{L}), \mathrm{Mn}(5.03 \mathrm{mg} / \mathrm{L}), \mathrm{Zn}(1.27 \mathrm{mg} / \mathrm{L}), \mathrm{Cu}(0.68$ $\mathrm{mg} / \mathrm{L}), \mathrm{Pb}(0.75 \mathrm{mg} / \mathrm{L})$ and $\mathrm{Ni}(0.03 \mathrm{mg} / \mathrm{L})$ were all observed during the dry season. The heavy metals also varied with the change of sampling locations. The dominance of these toxic element in the surface water of River Ogbere followed the sequence: $\mathrm{Mn}>\mathrm{Fe}>\mathrm{Zn}>\mathrm{Cu}>\mathrm{Cr}>\mathrm{Pb}>\mathrm{Ni}>\mathrm{Cd}$. The anthropogenic activities around the study area were observed to have increased the influx of toxic metals at both upstream and downstream sections of the river. In view of the high human activities along the river, River Ogbere appeared to have been polluted visibly. The constant water quality monitoring and development of River Ogbere safety plans is recommended.
\end{abstract}

\section{Keywords}

River Water Quality, Pollution, Toxic Metals, Anthropogenic Activities, 
Water Quality

\section{Introduction}

The input and accumulation of toxic pollutants from human activities are the main sources of metal distribution in the water phases of surface waters and as such, the control of these toxic substances is regarded as the best safety plan and management of surface water bodies. According to Taiwo [1], at least 27\% of Nigerians depend solely on surface water as a major source for domestic use. Unfortunately, most of these potable water sources are being contaminated with various pollutants from point and non-point sources, thus causing an adverse impact on human health and aquatic life [2]. Point sources of the toxic metals such as mining, agricultural activities, sewage disposal can be controlled while non-point sources such as surface, underground and fluvial inputs seem to be difficult to control. As toxic metals cannot be degraded, they are deposited, assimilated or incorporated in the water and its sediment. These non-biodegradable metallic chemical elements have a relatively high density, toxicity at low concentrations, and tend to accumulate in the sediment of waterways in association with organic and inorganic matter in the sediment [3]. [4] Storelli claimed that toxic metals have a particular significance in eco-toxicology since they are highly persistent and all have the potential to be toxic to living organisms. The presence of these metals in the environment has been a source of concern to environmentalists, government agencies and health practitioners as a result of their health implication, which is hazardous and toxic to man [5]. The presence of toxic metals has far-reaching consequences on man and their effects include the onset of cancers of the skin, lung and nasal regions [6]. Toxic metals are commonly found in natural waters and some are essential to live organisms, yet they may become highly toxic when present in high concentrations. Among environmental pollutants, metals are of particular concern; due to their potential toxic effects and ability to bio-accumulate in aquatic ecosystems [7]. Therefore, metals may bio-accumulate and bio-magnify via the food chain and finally assimilated by humans resulting in health risks [8].

Ibadan is the capital of Oyo state and is located in Southwestern Nigeria. The city is reported to be the largest indigenous city in West Africa and 2006 census estimated its population at over 3.8 million. The city covers an area of about 240 $\mathrm{km}^{2}$ [9]. One of the main problems facing Ibadan is the indiscriminate dumping of both solid and liquid wastes which are domestic in nature, runoff from agricultural activities and industrial waste disposal being deposited into drains, stream channels and subsequently the river. Thus, the quality of river in Ibadan is getting vastly deteriorated due to improper land management as well as poor waste management practices.

River Ogbere, one of the major rivers in Ibadan which serves several settlements in Ibadan metropolis is located in the south-western part of Ogunpa 
drainage basin on geographic grid reference longitude $3^{\circ} 56^{\prime} 25^{\prime \prime} \mathrm{E}$ and latitude $7^{\circ} 19^{\prime} 32 \mathrm{~N}$ with an estimated elevation of $174 \mathrm{~m}$ above the sea level. River Ogbere basin is covered mainly by ferruginous tropical soil on basement complex rock and rugged relief, occupying an area of $52.88 \mathrm{sq} \cdot \mathrm{km}$ in the tropical rainforest of Nigeria [10]. The major climatic season is wet (March-October) and dry season (November-February) with an average rainfall volume of $800 \mathrm{~mm}$ at onset and $1500 \mathrm{~mm}$ at its peak.

The study therefore investigated the distribution of potentially toxic metals concentration across one kilometer $(1 \mathrm{Km})$ stretch of the river based on accessibility and interference of human activities.

\section{Materials and Methods}

The sampling points were selected along 1 kilometre stretch of the river with six (6) points varying at the distance of 200 metres (Figure 1). The water samples were collected from a depth of one feet $(1 \mathrm{ft})$ below the surface thrice each season by grab sampling technique to reflect the present water quality status of the river. The samples were kept in a pre-cleaned 2.5 litres plastic polyethylene terephthalate PET bottles with addition of $2 \mathrm{~mL}$ concentrated $\mathrm{HNO}_{3}$ in order to preserve the metals and also to avoid precipitation.

The $\mathrm{pH}$ and conductivity of the water samples were determined in-situ with a pocket size HANNA COMBO pH/Conductivity metre. For the analysis of the total heavy metal (both dissolved and suspended) concentration, $100 \mathrm{~mL}$ of water

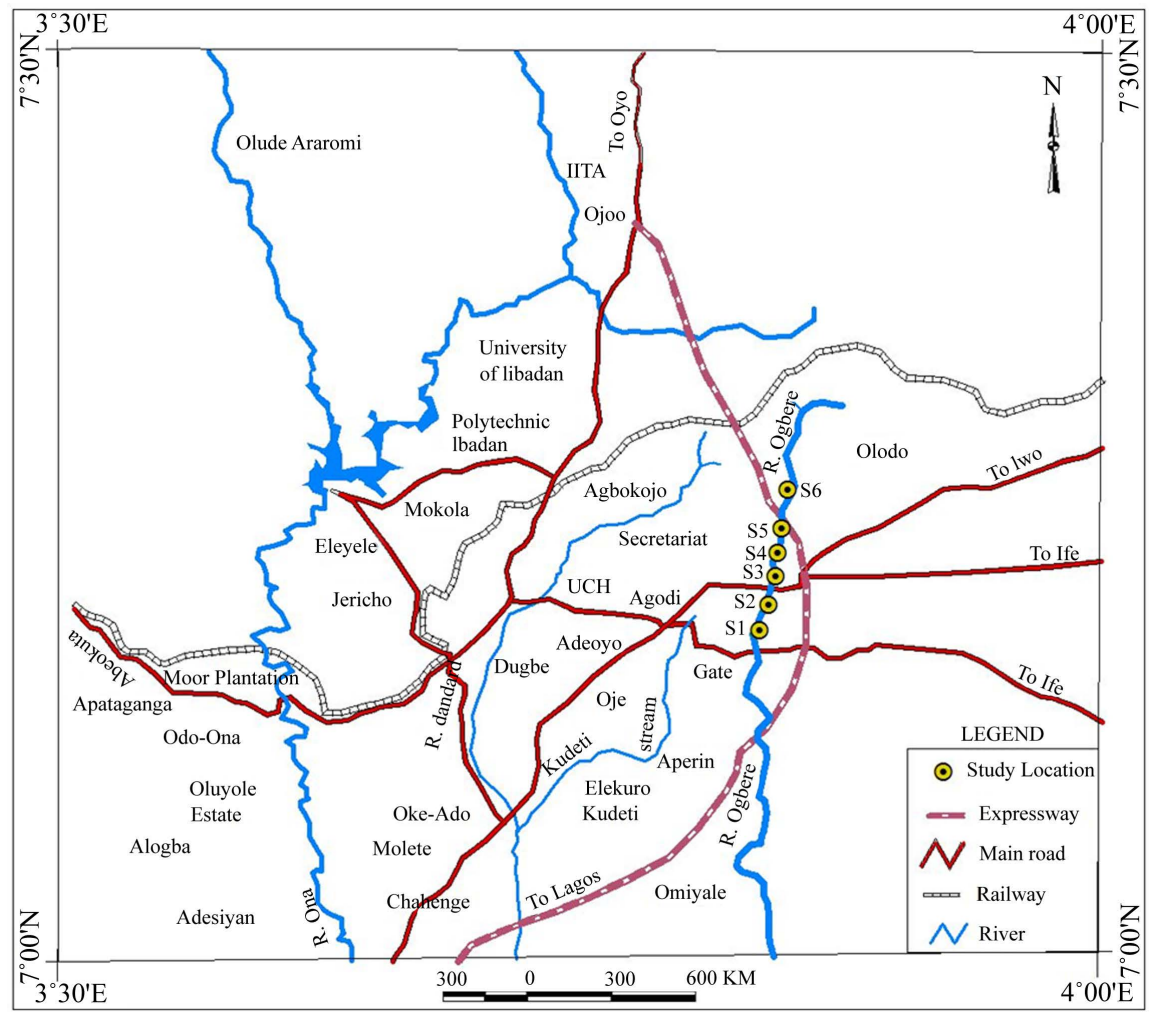

Figure 1. Map of Ogbere River showing sampling points. 
samples were digested with $5 \mathrm{~mL}$ of nitric acid by heating slowly on a hot plate and evaporated to $20 \mathrm{~mL}$. This was filtered and made up to the volume of $50 \mathrm{~mL}$ with distilled water for analysis of eight heavy metals viz: $\mathrm{Fe}, \mathrm{Mn}, \mathrm{Zn}, \mathrm{Cd}, \mathrm{Cu}$, $\mathrm{Cr}, \mathrm{Pb}$ and $\mathrm{Ni}$ using atomic absorption spectrophotometer (Buck Scientific model 210 VGP) [11]. The obtained data were subject to statistical analysis to test the analysis of variance (ANOVA) and comparing with the world health organisation standard for domestic use using SPSS statistical package Figure 2.

\section{Results and Discussion}

The water samples exhibited an alkaline $\mathrm{pH}$ in the range of $7.60-7.83$ and $7.40-$ 7.67 for wet and dry season respectively. Seasonal mean values of $\mathrm{pH}$ varied from 7.63 in wet season to 7.57 in dry season (Table 1). The lowest $\mathrm{pH}$ value was observed in dry season which may be due to dilution effect of rain water. However, mean values of $\mathrm{pH}$ across sampling point are not significantly different from each other. The observed values, however were all within the safe limit for drinking purpose [12]. Similar trend was also observed in the case of conductivity. The values of conductivity ranged from $236.67-280.67 \mu \mathrm{s} / \mathrm{cm}$ and 313.3 $353.3 \mu \mathrm{s} / \mathrm{cm}$ in wet season and dry season respectively. Table 1 shows the seasonal mean values of conductivity in the range of $252.1 \mu \mathrm{s} / \mathrm{cm}$ in wet season and $328.3 \mu \mathrm{s} / \mathrm{cm}$ in dry season. The water samples showed slight variations in conductivity seasonally.

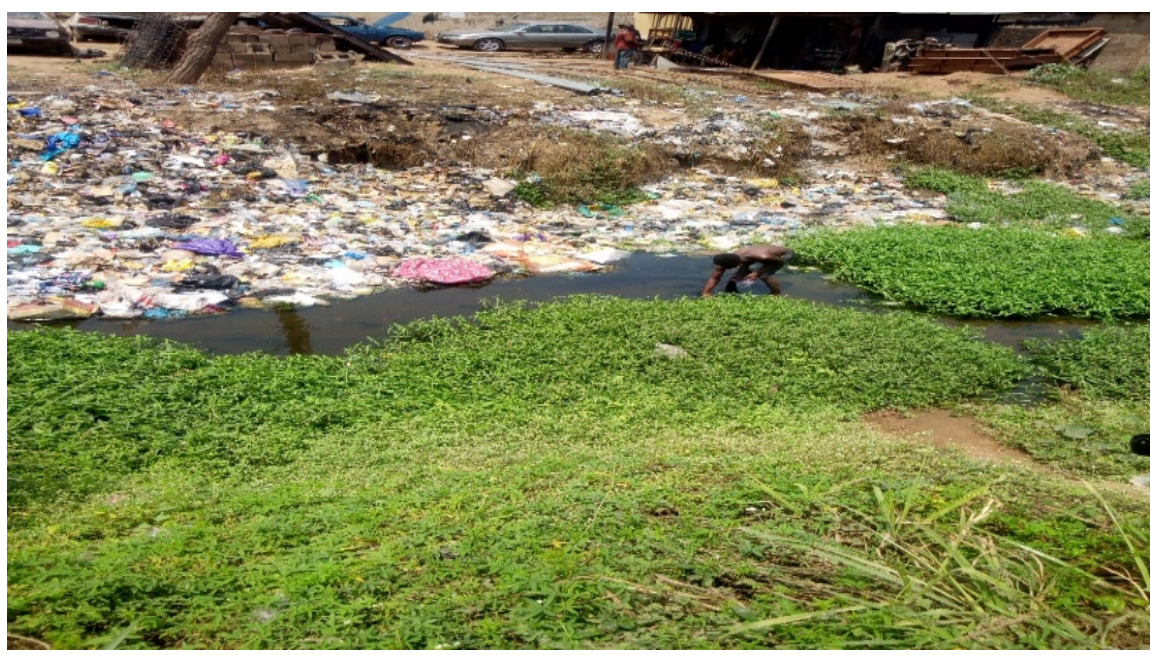

Figure 2. River Ogbere with excessive waste dumping at the commercial areas.

Table 1. Changes in $\mathrm{pH}$ and conductance of surface water of River Ogbere.

\begin{tabular}{cccccccccc}
\hline Parameters & Season & S1 & S2 & S3 & S4 & S5 & S6 & Average & WHO Standard \\
\hline \multirow{2}{*}{$\mathrm{pH}$} & Wet & 7.83 & 7.80 & 7.83 & 7.70 & 7.60 & 7.63 & 7.73 & \multirow{2}{*}{ ( } \\
& Dry & 7.67 & 7.67 & 7.47 & 7.47 & 7.40 & 7.57 & 7.57 & \\
\hline \multirow{2}{*}{ E.C $(\mu \mathrm{s} / \mathrm{cm})$} & Wet & 236.7 & 241.7 & 251.3 & 240.0 & 262.3 & 280.7 & 280.7 & $10-1000$ \\
& Dry & 333.3 & 313.3 & 323.3 & 313.3 & 333.3 & 353.3 & 353.3 & \\
\hline
\end{tabular}


All the 12 surface water samples of river Ogbere were analysed for Fe, Mn, Zn, $\mathrm{Cu}, \mathrm{Cd}, \mathrm{Cr}, \mathrm{Pb}$ and $\mathrm{Ni}$. The presence of $\mathrm{Fe}, \mathrm{Mn}, \mathrm{Zn}, \mathrm{Cu}, \mathrm{Cr}, \mathrm{Pb}$ and $\mathrm{Ni}$ were detected in all samples with an overall mean values of $4.82,4.27,1.20,0.36,0.47$, $0.60,0.30 \mathrm{mg} / \mathrm{L}$ in dry season and $0.76,3.73,0.11,0.07,0.05,0.02$ and $0.01 \mathrm{mg} / \mathrm{L}$ in wet season (Table 2). However, Cd was detected in only $75 \%$ of the water samples with overall mean values of $0.02 \mathrm{mg} / \mathrm{L}$ in dry season and $0 \mathrm{mg} / \mathrm{L}$ in wet season. Except for $\mathrm{Fe}, \mathrm{Mn}$ in both seasons, $\mathrm{Cr}$ and $\mathrm{Pb}$ in dry season, the observed metals were all in a safe limit for drinking [12] and crop production [13]. The seasonal distribution of the mean concentration of metals in this study have been shown to be in order:

$$
\mathrm{Mn}>\mathrm{Fe}>\mathrm{Zn}>\mathrm{Cu}>\mathrm{Cr}>\mathrm{Pb}>\mathrm{Ni}>\mathrm{Cd} \text { (Wet season, 2019); }
$$$$
\mathrm{Fe}>\mathrm{Mn}>\mathrm{Zn}>\mathrm{Pb}>\mathrm{Cr}>\mathrm{Cu}>\mathrm{Ni}>\mathrm{Cd} \text { (Dry season, 2019). }
$$

Iron is one of the most abundant metals in the earth's crust. It is an essential trace element required by all forms of life. Iron values across the sampling points in both seasons recorded an average of $0.76 \mathrm{mg} / \mathrm{L}$ in wet season and $4.82 \mathrm{mg} / \mathrm{L}$ in dry season, which is above the $0.3 \mathrm{mg} / \mathrm{L} \mathrm{WHO}$ permissible limit. Similar study was observed by Alani et al. [14] on River Ogun. These high iron values might be due to run-off from domestic and urban wastes. Excess iron concentration impairs the ability of body to regulate iron absorption leading to siderosis in liver, pancreas and heart. Manganese concentration level in the river accounts for an average value of $3.73 \mathrm{mg} / \mathrm{L}$ and $4.27 \mathrm{mg} / \mathrm{L}$ in wet and dry season respectively.

Table 2. Average concentration of toxic metals in surface water of River Ogbere.

\begin{tabular}{|c|c|c|c|c|c|c|c|c|c|}
\hline Metals & Season & S1 & S2 & S3 & S4 & S5 & S6 & Average & WHO Standard \\
\hline \multirow{2}{*}{$\begin{array}{c}\mathrm{Fe} \\
(\mathrm{mg} / \mathrm{L})\end{array}$} & Wet & 0.49 & 0.10 & 0.58 & 0.93 & 1.97 & 0.47 & 0.76 & \multirow{2}{*}{0.3} \\
\hline & Dry & 5.12 & 5.44 & 3.41 & 5.44 & 4.68 & 4.80 & 4.82 & \\
\hline \multirow{2}{*}{$\begin{array}{c}\mathrm{Mn} \\
(\mathrm{mg} / \mathrm{L})\end{array}$} & Wet & 3.59 & 3.60 & 3.20 & 3.61 & 3.68 & 4.70 & 3.73 & \multirow{2}{*}{0.4} \\
\hline & Dry & 4.37 & 3.71 & 3.65 & 4.38 & 4.48 & 5.03 & 4.27 & \\
\hline \multirow{2}{*}{$\begin{array}{c}\mathrm{Zn} \\
(\mathrm{mg} / \mathrm{L})\end{array}$} & Wet & 0.15 & 0.13 & 0.04 & 0.09 & 0.12 & 0.12 & 0.11 & \multirow{2}{*}{5.0} \\
\hline & Dry & 1.27 & 1.40 & 1.15 & 1.07 & 1.16 & 1.14 & 1.20 & \\
\hline \multirow{2}{*}{$\underset{(\mathrm{mg} / \mathrm{L})}{\mathrm{Cu}}$} & Wet & 0.05 & 0.08 & 0.03 & 0.09 & 0.09 & 0.08 & 0.07 & \multirow{2}{*}{2.0} \\
\hline & Dry & 0.35 & 0.44 & 0.31 & 0.51 & 0.29 & 0.27 & 0.36 & \\
\hline \multirow{2}{*}{$\begin{array}{c}\mathrm{Cd} \\
(\mathrm{mg} / \mathrm{L})\end{array}$} & Wet & ND & $\mathrm{ND}$ & ND & ND & $\mathrm{ND}$ & 0.01 & 0.00 & \multirow{2}{*}{0.03} \\
\hline & Dry & 0.01 & 0.01 & 0.07 & 0.04 & $\mathrm{ND}$ & 0.01 & 0.02 & \\
\hline \multirow{2}{*}{$\underset{(\mathrm{mg} / \mathrm{L})}{\mathrm{Cr}}$} & Wet & 0.08 & 0.04 & 0.05 & 0.04 & 0.06 & 0.05 & 0.05 & \multirow{2}{*}{0.1} \\
\hline & Dry & 0.47 & 0.20 & 0.43 & 0.63 & 0.68 & 0.38 & 0.47 & \\
\hline \multirow{2}{*}{$\begin{array}{c}\mathrm{Pb} \\
(\mathrm{mg} / \mathrm{L})\end{array}$} & Wet & 0.02 & 0.01 & 0.01 & 0.01 & 0.01 & 0.02 & 0.02 & \multirow{2}{*}{0.01} \\
\hline & Dry & 0.54 & 0.75 & 0.70 & 0.71 & 0.62 & 0.29 & 0.60 & \\
\hline \multirow{2}{*}{$\begin{array}{c}\mathrm{Ni} \\
(\mathrm{mg} / \mathrm{L})\end{array}$} & Wet & 0.01 & 0.01 & 0.01 & ND & ND & 0.02 & 0.01 & \multirow{2}{*}{0.07} \\
\hline & Dry & 0.03 & 0.03 & 0.03 & 0.04 & 0.01 & 0.03 & 0.03 & \\
\hline
\end{tabular}

${ }^{*}$ ND: Not Detected. 
These values exceed the permissible limit of $0.4 \mathrm{mg} / \mathrm{L}$ [12]. The higher manganese concentration may be attributed to the addition of agricultural run-off, sewage and domestic wastes in river. [15] Moyosore also reported high concentration of manganese in Ogun River which agrees with the result obtained in this study. Zinc is a ubiquitous metal present in the environment. Zinc concentration in Ogbere river recorded a seasonal mean value of $0.11 \mathrm{mg} / \mathrm{L}$ in wet season and $1.20 \mathrm{mg} / \mathrm{L}$ in dry season, which is within the acceptable limit for potable water of $5 \mathrm{mg} / \mathrm{L}$ [12]. Zinc recorded in the study is lower than that was obtained by [16] Aliyu et al. who carried out physicochemical and elemental quality of water from River Lavun, Bida, Niger State. Zinc deficiency causes anaemia and retardation of growth and development. Copper is an important metal element to human health. It combines with specific proteins to yield enzymes that functions as catalyst to help the human body (Sivaperumal et al., 2007). Copper in this study recorded an average mean of $0.07 \mathrm{mg} / \mathrm{L}$ and $0.36 \mathrm{mg} / \mathrm{L}$ in wet and dry seasons respectively. These values were within the permissible limits of $2 \mathrm{mg} / \mathrm{L}$ [12]. This agrees with Aliyu et al. [16] on River Lavun, Bida. Its presence could be as a result of addition from agricultural runoff, sewage which causes anaemia and kidney damage. Cadmium is widely known to be highly toxic non-essential heavy metal. Cadmium concentration in the river during the period of study which recorded a mean value of $0.00 \mathrm{mg} / \mathrm{L}$ and $0.01 \mathrm{mg} / \mathrm{L}$ in wet and dry season respectively Figure 3. These values are within acceptable limit in wet season but was above the acceptable limit of $0.003 \mathrm{mg} / \mathrm{L}$ of WHO standard. Similar trend was observed by Aliyu et al. [16] in River Lavun, Bida. The increase in cadmium concentration in dry season could probably be attributed to decrease in volume of water and increase in temperature. Chromium is an essential trace element that is required in small amounts for carbohydrate metabolism. Chromium concentration in River Ogbere recorded an average of $0.05 \mathrm{mg} / \mathrm{L}$ in wet season and $0.47 \mathrm{mg} / \mathrm{L}$ in dry season which is below the acceptable limit of $0.1 \mathrm{mg} / \mathrm{L}$ of WHO. Similar result was obtained by [17] Yusuf et al. of Saba River, Osogbo. Chromium and Cadmium work together and the combined toxicity of these two metals is greater than the sum of their individual toxicity [18]. Lead concentration in River Ogbere recorded an average mean of $0.02 \mathrm{mg} / \mathrm{L}$ in wet season and 0.60 $\mathrm{mg} / \mathrm{L}$ in dry season Figure 4. Its concentration falls within WHO permissible limit in wet season but slightly above the limit in dry season Table 3. This was similar to lead concentration reported by [19] Dike et al. in River Jakara, Kano State. Lead concentration amongst the sampling points showed no statistically significant difference $(\mathrm{P}>0.05)$ except for point $\mathrm{A}$ and $\mathrm{F}$ in the dry season Table 4. Nickel is a moderately toxic element that recorded a mean value of $0.01 \mathrm{mg} / \mathrm{L}$ in wet season and $0.03 \mathrm{mg} / \mathrm{L}$ in dry season. This values fall within the $0.07 \mathrm{mg} / \mathrm{L}$ WHO standard in the dry season but slightly above in the wet season. These values are lower that what was obtained by Aliyu et al. [16]. Exposure to excess concentration of nickel may cause toxic effect in the respiratory tract and immune system [20]. 


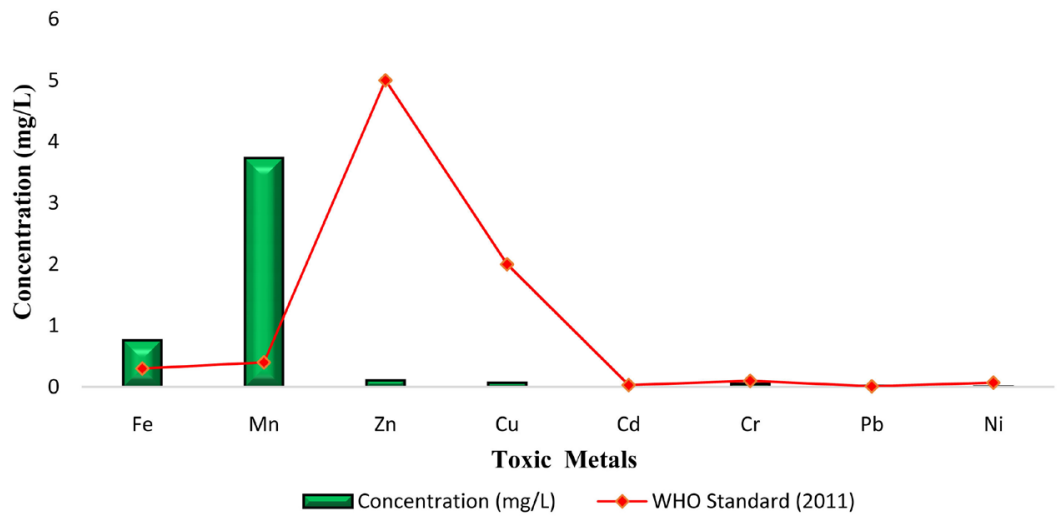

Figure 3. Graphical interpretation of trace metal concentration in wet season.

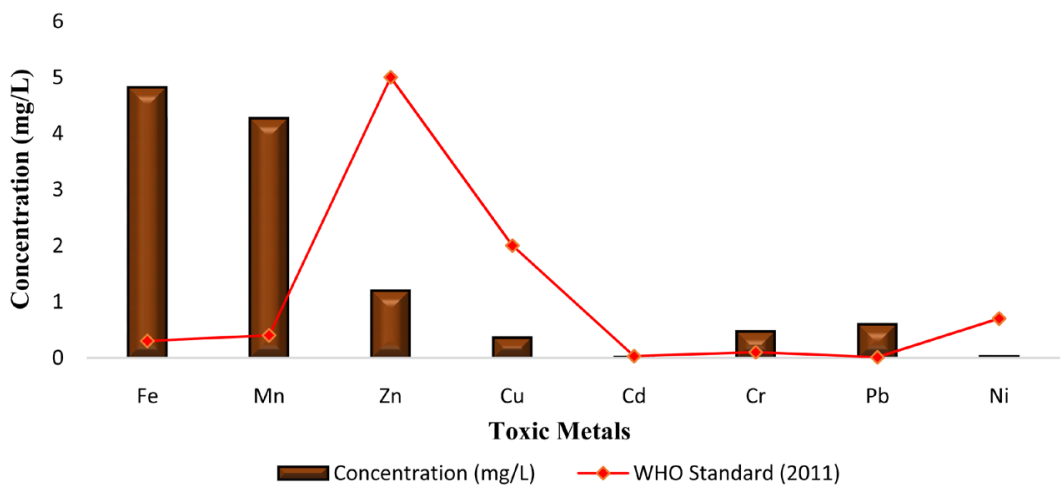

Figure 4. Graphical interpretation of trace metal concentration in dry season.

Table 3. Spatial changes in toxic metal content of River Ogbere.

\begin{tabular}{cccccccccc}
\hline \multirow{2}{*}{ Location } & Fe & Mn & $\mathrm{Zn}$ & $\mathrm{Cu}$ & $\mathrm{Cd}$ & $\mathrm{Cr}$ & $\mathrm{Pb}$ & $\mathrm{Ni}$ \\
\cline { 2 - 9 } & \multicolumn{7}{c}{$\mathrm{mg} / \mathrm{L}$} \\
S1 & 4.63 & 0.78 & 1.12 & 0.30 & 0.01 & 0.39 & 0.52 & 0.02 \\
S2 & 5.34 & 0.11 & 1.27 & 0.36 & 0.01 & 0.16 & 0.74 & 0.02 \\
S3 & 2.83 & 0.45 & 1.11 & 0.28 & 0.07 & 0.38 & 0.69 & 0.02 \\
S4 & 4.51 & 0.77 & 0.98 & 0.42 & 0.04 & 0.59 & 0.70 & 0.04 \\
S5 & 2.71 & 0.80 & 1.04 & 0.20 & 0.00 & 0.62 & 0.61 & 0.01 \\
S6 & 4.33 & 0.33 & 1.02 & 0.19 & 0.00 & 0.33 & 0.27 & 0.01 \\
\hline
\end{tabular}

Table 4. Correlation of different toxic metals of the surface water of River Ogbere.

\begin{tabular}{ccccccccc}
\hline & $\mathrm{Mn}$ & $\mathrm{Fe}$ & $\mathrm{Cu}$ & $\mathrm{Zn}$ & $\mathrm{Pb}$ & $\mathrm{Cd}$ & $\mathrm{Ni}$ & $\mathrm{Cr}$ \\
\hline $\mathrm{Mn}$ & 1.000 & & & & & & & \\
$\mathrm{Fe}$ & 0.324 & 1.000 & & & & & & \\
$\mathrm{Cu}$ & -0.210 & 0.509 & 1.000 & & & & & \\
$\mathrm{Zn}$ & -0.175 & 0.082 & 0.122 & 1.000 & & & & \\
$\mathrm{~Pb}$ & -0.881 & 0.050 & 0.549 & 0.146 & 1.000 & & & \\
$\mathrm{Cd}$ & 0.605 & -0.319 & -0.307 & -0.061 & -0.641 & 1.000 & & \\
$\mathrm{Ni}$ & 0.121 & -0.405 & 0.267 & 0.043 & -0.204 & 0.346 & 1.000 & \\
$\mathrm{Cr}$ & 0.123 & -0.459 & -0.015 & -0.523 & 0.000 & -0.478 & -0.460 & 1.000
\end{tabular}

NB: Correlation is significant at the 0.05 level. 


\section{Conclusion}

The occurrence of enhanced concentration of toxic metals in the studied river was a clear indication of anthropogenic pollution from population increase and urbanization coupled with a lack of proper waste disposal systems. These call for improvement before the trace metals plough back into the food chain to cause a serious hazard in man. The following conclusion was drawn from the study. The speciation of toxic metals in the river Ogbere led to the detection of differing concentration of metal in the river water. The study also provides baseline information on the concentration of the metal in the river with which future anthropogenic influences could be evaluated. There was a variation in the toxic metal concentration across the different sites indicating a corresponding variation in the activities leading to deposition of these metals at the different points due to different rates of metal ion mobility and difference in solubility. The study confirmed that the river water had a very slight metal concentration for the eight metals in which Iron, Manganese and Zinc have the highest concentration in both seasons. Copper, Zinc, Cadmium and Nickel fell within the range of WHO standards for river water. Statistical analysis at $95 \%$ confidence limit shows that there is no significant difference observed between the sampling point as a result of human activities such as farming, dumpsites, auto-mechanic and marketing influence.

\section{Conflicts of Interest}

The authors declare no conflicts of interest regarding the publication of this paper.

\section{References}

[1] Taiwo, A.M., Olujimi, O.O., Bamgbose, O. and Arowolo, T.A. (2012) Surface Water Quality Monitoring in Nigeria. Situational Analysis and Future Management Strategy. In: Voudouris, Ed., Water Quality Monitoring and Assessment, InTech, London, 301-322. https://doi.org/10.5772/33720

http://www.intechopen.com/books/water-quality-monitoring-and-assessment/surfa ce-water-quality-monitoring-in-nigeria-situational-analysis-and-future-manageme nt-strategy

[2] Lawson, E.O. (2011) Physico-Chemical Parameters and Heavy Metal Contents of Water from the Mangrove Swamps of Lagos Lagoon, Lagos, Nigeria. Advances in Biological Research, 5, 8-21.

[3] Huong, N.T.L., Ohtsubo, M., Li, L., Higashi, T. and Kanayama, M. (2008) Assessment of the Water Quality of Two Rivers in Hanoi City and Its Suitability for Irrigation Water. Paddy Water Environment, 6, 257-262. https://doi.org/10.1007/s10333-008-0125-y

[4] Storelli, M., Storelli, A., Marano, C. and Bruno, R. (2005) Trace Elements in Loggerhead Turtles (Carellacarella) from the Eastern Mediterranean Sea: Overview and Evaluation. Environmental Science and Pollution Research, 135, 163-170. https://doi.org/10.1016/j.envpol.2004.09.005

[5] Hacioglu, N. and Dulger, B. (2009) Monthly Variation of Some Physicochemical 
and Microbial Parameters in Biga Stream (Biga, Canakkale, Turkey). African Journal of Biotechnology, 8, 1927-1937.

[6] Fatoki, O.S., Lujiza, N. and Ogunfowokan, A.O. (2002) Trace Metal Pollution in Umtata River. Water SA, 28, 183-190. https://doi.org/10.4314/wsa.v28i2.5160

[7] Censi, P., Spoto, S., Saino, F., Sprovieri, S., Mazzola, A. and Nardone, G. (2006) Heavy Metals in Coastal Water Systems: A Case Study from the North-Western Gulf of Thailand. Chemistry International, 64, 1167-1176. https://doi.org/10.1016/j.chemosphere.2005.11.008

[8] Agah, H., Leermakers, M., Elskens, M., Fatemi, R. and Baeyens, W. (2009) Accumulation of Trace Metals in the Muscles and Liver Tissues of Five Fish Species from the Persian Gulf. Environmental Monitoring and Assessment, 157, 499-514. https://doi.org/10.1007/s10661-008-0551-8

[9] Onianwa, et al. (2013) Impact of Effluent of an Industrial Estate on Oruku River in Southwestern Nigeria. World Applied Sciences Journal, 21, 1075-1083.

https://www.researchgate.net/publication/288077456_Impact_of_effluent_of_an_in dustrial_estate_on_Oruku_River_in_Southwestern_Nigeria

[10] Ajibade, L.T., Ifabiyi, L.P., Iroye, K.A. and Ogunteru, S. (2010) Morphometric Analysis of Ogunpa and Ogbere Drainage Basins, Ibadan, Nigeria. Ethiopian Journal of Environmental Studies and Management, 3, 13-19. https://doi.org/10.4314/ejesm.v3i1.54392

[11] APHA (2005) Standard Methods for the Examination of Water and Wastewater. 21st Edition.

[12] WHO (2011) Manganese in Drinking Water. Background Document for Development of WHO Guidelines for Drinking-Water Quality.

[13] FAO (1975) Population, Food Supply, and Agriculture Development, 337 (1973). FAO, Rome.

[14] Alani, R., Alo, B. and Ukoakonam, F. (2014) Preliminary Investigation of the State of Pollution of Ogun River at Kara Abattoir, Near Berger, Lagos. International Journal of Environmental Science and Technology, 2, 11-23.

[15] Moyosore, J.O., Sridhar, M.K.C., Coker, A.O. and Mumuni, A. (2014) Iron and Manganese Levels of Groundwater in Selected Areas in Ibadan and Feasible Engineering Solutions. European Scientific Journal, 10, 137-153.

[16] Aliyu, A., Yakubu, K.E. and Oyi, A. (2018) Assessment of Physicochemical and Elemental Quality of Water from River Lavun, Bida, Niger State, Nigeria. Journal of Pharmacy \& Bioresources, 15, 180-187. https://doi.org/10.4314/jpb.v15i2.12

[17] Yusuf, S.T., Kwaga, J.K.P., Okolocha, E.C. and Bello, M. (2017) Phenotypic Occurrence of Methicillin-Resistant Staphylococcus aureus in Camels Slaughtered at Kano Abattoir, Kano, Nigeria. Sokoto Journal of Veterinary Sciences, 15, 29-35. http://www.sokvetjournal.net/index.php/past-issues?id=290 https://doi.org/10.4314/sokjvs.v15i2.4

[18] Nubi, O.A., Oyediran, L.O. and Nubi, A.T. (2011) Inter-Annual Trends of Heavy Metals in Marine Resources from the Nigerian Territorial Waters. African Journal of Environmental Science and Technology, 5, 104-110.

[19] Dike, N.I., Ezealor, A.U. and Oniye, S.J. (2004) Concentration of Pb, Cu, Fe and Cd during the Dry Season in River Jakara, Kano, Nigeria. Chemical Class Journal, 1, 78-81.

[20] Cempel, M. and Nikel, G. (2006) Nickel: A Review of Its Sources and Environmental Toxicology. Polish Journal of Environmental Studies, 15, 375-382. 